Dikirim: 28 April 2017 Diterbitkan: 1 Juni 2017

\title{
Kelas edukasi menyusui sebagai penunjang keberhasilan ASI eksklusif
}

\section{Breastfeeding education classes as a support for exclusive breastfeeding success}

Shelly Puspa Anggraini ${ }^{1}$, Retna Siwi Padmawati ${ }^{2}$, Madarina Julia ${ }^{3}$

\begin{abstract}
Purpose: The purpose of this paper was to examine the difference of maternal participation in breastfeeding education class AIMI (Indonesian Breastfeeding Association) and the success of exclusive breastfeeding. Methods: A cross-sectional study was conducted involving 186 mothers. We used in-depth interviews of mothers who had attended AIMI Yogyakarta's breastfeeding education class. Results: As many as $88.6 \%$ of respondents gave exclusive breastfeeding. Of those who attended only one class, $88.9 \%$ gave exclusive breastfeeding, while $88.6 \%$ in the group who attended the two educational classes gave exclusive breastfeeding. There was no difference between mothers who attended one class or two classes of education on exclusive breastfeeding success. Conclusion: This study contributes to the knowledge that there is no difference between mothers attending one class or two classes of education on exclusive breastfeeding success.
\end{abstract}

Keywords: education class; exclusive breastfeeding; Indonesian breastfeeding association

\footnotetext{
${ }^{1}$ Departemen Biostatistik, Epidemiologi dan Kesehatan Populasi, Fakultas Kedokteran, Universitas Gadjah Mada (Email: shellypuspaa@gmail.com)

${ }^{2}$ Departemen Perilaku Kesehatan, Lingkungan dan Kedokteran Sosial, Fakultas Kedokteran, Universitas Gadjah Mada

${ }^{3}$ Departemen Ilmu Kesehatan Anak, Fakultas Kedokteran, Universitas Gadjah Mada
} 


\section{PENDAHULUAN}

Perbaikan gizi anak dengan memberikan ASI eksklusif sejak lahir hingga usia 6 bulan (1). Kandungan gizi pada ASI cukup untuk memenuhi kebutuhan energi dan protein hingga usia 6 bulan (2). Namun, cakupan ASI eksklusif di provinsi DIY tahun 2012 sebesar 48\%, masih jauh dibandingkan dengan target departemen kesehatan (3).

Faktor yang memengaruhi keberhasilan ibu dalam pemberian ASI eksklusif adalah pendidikan, pengetahuan dan pengalaman (4). Selain itu, informasi, dukungan keluarga, komunitas dan sistem layanan kesehatan diperlukan untuk meningkatkan kepercayaan diri ibu dalam memberikan ASI eksklusif, dan mengatasi setiap masalah ibu terkait pemberian ASI eksklusif (5).

Sumber informasi terpercaya dan mudah diakses berguna untuk menambah pengetahuan dan wawasan mengenai urgensi ASI. Salah satu sumber informasi adalah konselor menyusui atau dengan mengikuti kelas edukasi menyusui. Edukasi menyusui dari kelas edukasi atau kelompok yang mendukung, memberikan pengaruh positif terhadap lama durasi menyusui (6). Pada kelompok yang diberikan edukasi, lebih banyak ibu yang memberikan ASI eksklusif dibandingkan dengan ibu yang tidak diberikan edukasi menyusui (7).

Kelas edukasi menyusui yang diselenggarakan oleh Asosiasi Ibu Menyusui Indonesia (AIMI) didampingi oleh konselor menyusui. Ibu diberikan informasi relevan dan diskusi mengenai persiapan menyusui hingga tantangan menyusui. Dengan mengikuti kelas edukasi menyusui diharapkan ibu dapat berhasil memberikan ASI eksklusif selama 6 bulan.

Melihat pentingnya ASI bagi pertumbuhan dan perkembangan bayi, serta kelas edukasi AIMI sebagai salah satu upaya meningkatkan pengetahuan ibu mengenai ASI, penelitian ini perlu dilakukan. Penelitian ini dilaksanakan dengan tujuan untuk mengkaji perbedaan keikutsertaan ibu dalam kelas edukasi menyusui AIMI (Asosiasi Ibu Menyusui Indonesia) dan keberhasilan dalam memberikan ASI eksklusif.

\section{METODE}

Penelitian kuantitatif ini menggunakan rancangan cross sectional dan pendekatan kualitatif dengan wawancara mendalam untuk mendukung data kualitatif. Responden penelitian ini adalah ibu-ibu yang pernah mengikuti kelas edukasi menyusui AIMI Yogyakarta dan ranting Bantul yang memenuhi kriteria sebagai berikut, ibu yang memiliki anak usia $>6$ bulan; alamat tempat tinggal jelas dan berada di wilayah kerja AIMI cabang Yogyakarta dan ranting Bantul; bersedia menjadi responden penelitian. Kriteria eksklusi untuk penelitian ini adalah terdapat kelainan kongenital sehingga bayi sulit menyusu; terdapat kelainan fisik pada ibu sehingga sulit menyusui; ibu memiliki penyakit berat sehingga tidak bisa menyusui.

Pengambilan sampel dengan total sampling. Dari 186 ibu yang pernah mengikuti kelas edukasi menyusui, didapat 38 orang yang memenuhi kriteria. Sebanyak 35 responden mengisi kuesioner, sedangkan 3 responden tidak memberikan feedback. Data mengenai keberhasilan memberikan ASI eksklusif diperoleh dari pengisian kuesioner oleh responden.

Kelas edukasi menyusui diadakan AIMI cabang Yogyakarta secara rutin sejak 2013. Kelas edukasi menyusui dibagi menjadi 2, kelas edukasi menyusui 1 untuk persiapan menyusui dan kelas edukasi menyusui 2 untuk persiapan ibu kembali berkegiatan. Setiap kelas berisikan 10-20 peserta, baik itu yang datang sendiri maupun berpasangan. Penyampaian materi dengan metode presentasi dan tanya jawab serta diselingi dengan pemutaran video.

Responden diperoleh dari data peserta kelas edukasi menyusui AIMI cabang Yogyakarta dan ranting Bantul tahun 2014-2016. Didapatkan 38 subjek memenuhi kriteria. Sebanyak 35 responden mengisi kuesioner yang sudah diberikan, sedangkan 3 responden tidak memberikan feedback. Pengisian kuesioner dilakukan tatap muka dan online. Pengisian kuesioner online dilakukan jika responden keberatan untuk ditemui atau sedang berada di luar kota. Sebanyak 25 responden mengisi kuesioner online dan 10 responden mengisi secara langsung. Wawancara mendalam dilakukan pada 4 responden.

\section{HASIL}

Tabel 1 menunjukkan distribusi subjek berdasarkan usia, pendidikan, pekerjaan, riwayat melahirkan dan usia bayi. Dari seluruh ibu yang bekerja, terdapat $17 \%$ ibu bekerja sebagai wiraswasta sehingga memiliki waktu kerja yang fleksibel karena bekerja di rumah. Rata-rata ibu bekerja di luar rumah selama 4-8 jam sehari.

Dari seluruh responden, sebesar 11,4\% tidak memberikan ASI eksklusif. Hampir semua ibu yang sudah menyapih anak dengan memberikan susu UHT atau susu formula sebagai pengganti ASI. 
Tabel 1. Distribusi frekuensi variabel penelitian

\begin{tabular}{lcc}
\hline \multicolumn{1}{c}{ Variabel } & \% & Mean \pm SD \\
\hline $\begin{array}{l}\text { Usia }(\mathrm{n}=35) \\
\text { Pendidikan }\end{array}$ & & $28,5 \pm 3,2$ \\
$\begin{array}{l}\text { Tinggi }(\mathrm{n}=35) \\
\text { Rendah (n=0) }\end{array}$ & 100 & \\
$\begin{array}{l}\text { Pekerjaan } \\
\text { Bekerja }(\mathrm{n}=21)\end{array}$ & & \\
Tidak bekerja (n=14) & 60 & \\
$\begin{array}{l}\text { Riwayat } \\
\text { melahirkan }\end{array}$ & 40 & \\
Primipara (n=33) & 94,3 & \\
Multipara (n-2) & 5,7 & \\
Usia bayi $(\mathrm{n}=35)$ & & $16,7 \pm 7,2$ \\
\hline
\end{tabular}

Tabel 2 menunjukkan penelitian ini tidak menemukan perbedaan antara ibu yang mengikuti satu kelas edukasi dan mengikuti dua kelas edukasi menyusui dengan keberhasilan ASI eksklusif.

Tabel 2. Proporsi ASI eksklusif dan tidak ASI eksklusif berdasarkan keikutsertaan ibu dalam kelas edukasi

\begin{tabular}{ccc}
\hline Kelas edukasi & $\begin{array}{c}\text { ASI Ekslusif } \\
(\mathbf{n = 3 1 )} \%\end{array}$ & $\begin{array}{c}\text { Tidak ASI } \\
\text { Eksklusif }(\mathbf{n = 4 )} \%\end{array}$ \\
\hline Mengikuti satu kelas edukasi & 88,9 & 11,1 \\
Mengikuti dua kelas edukasi & 88,6 & 11,4 \\
\hline
\end{tabular}

Sebanyak 34,3\% responden mengatakan bahwa kelas edukasi menyusui AIMI merupakan sumber yang berpengaruh terhadap keberhasilan ibu memberikan ASI eksklusif. Responden mengetahui AIMI dari media sosial. Pemaparan responden berikut:

"saya tahunya dari media sosial, dari facebook." (informan 1).

"Dari fb, malah ikut grupnya, disitu bisa membaca informasi sepuasnya” (informan 2).

Menurut responden materi yang diberikan sudah bagus, penyampaian materi cukup jelas, pemateri juga dinilai menguasai materi dan cukup komunikatif. Hanya saja dirasa waktu yang diberikan masih kurang, dan ada juga yang mengatakan bahwa biaya untuk mengikuti kelas edukasi cukup mahal.

"bagus sih. Bagus, sudah cukup. Tapi ya itu mahal" (informan 1)

"sebenarnya isi materi lebih dari ekspektasi, hanya ya itu waktunya kurang kalau menurut saya. Karena memakai sesi tanya jawab" (informan 3).

Banyak responden yang hanya mengikuti satu kelas edukasi saja lebih banyak dibandingkan ibu yang mengikuti dua kelas edukasi. Hal ini dikarenakan waktu yang kebetulan bersamaan dengan acara yang lain, ada yang dikarenakan kendala transportasi. Namun ada juga yang mengikuti seluruh rangkaian kelas edukasi, termasuk kelas edukasi MPASI.

"itu waktu itu saya masih tergantung transportnya. Lalu, sulit karena mengikuti jadwal suami...” (informan 2).

"Saya ikut KE1 dan MPASI. KE2 baru mau ikut. Waktu itu jadwalnya berbenturan dengan acara keluarga kalau tidak salah.” (informan 3)

"Jadi saya ikut kelas lima kali. Empat kali kelas, satu kali sharing di Bantul. Di Bantul dua kali, yang pertama itu. kalau kata suami biar ilmunya komplit" (informan 4).

Motivasi mengikuti kelas edukasi menyusui ada beragam. Responden yang mengikuti kelas edukasi ketika hamil mengatakan tujuan mereka adalah memiliki bekal saat praktik menyusui nanti. Namun ada yang mengikuti kelas edukasi menyusui ketika anak sudah lahir, karena masih ingin belajar.

"saya ikut kelas edukasi usia anak dah 1 tahun lebih. Saya masih ingin belajar mba, siapa tahu di kemudian hari tertarik punya anak lagi. Atau minim saya tahu, saya dulu kok bisa mengalami masalah begitu mengapa? Setidaknya saya bisa share ke orang-orang terdekat saya manfaat ASI" (informan 3).

Kendala yang dihadapi ibu selama proses menyusui adalah perbedaan pendapat ibu dengan anggota keluarga lain. Responden memaparkan bahwa edukasi menyusui tidak hanya dibutuhkan oleh ibu, namun juga dibutuhkan anggota keluarga lain.

"di depan saya mertua setuju tanpa dot. Belakangan beliau selalu marah-marah bilang 'betapa konyolnya saya beranggapan bahwa bayi bisa diberi minum tanpa dot'. Berada di bawah tekanan, akhirnya suami saya pun menekan saya mengharuskan saya untuk mau pakai dot, akhirnya ya saya yang mengalah” (informan 3).

"saya bawa suami dan mertua saya ke klinik laktasi. Disitu pandangan mertua saya mulai berubah. Karena mertua mantap, suami saya juga sudah ikut konsul, jadi pengetahuannya juga sudah bertambah. Dua-duanya mantap kembali ke ASI. Menurut saya kendala saya ada di perbedaan pandangan dengan orang terdekat. Ya 
karena itu tadi, mungkin karena kurang paparan informasi” (informan 3).

Sebanyak 28,6\% responden mengatakan bahwa dukungan keluarga terutama suami berpengaruh dalam keberhasilan ibu memberikan ASI eksklusif. Kepercayaan diri ibu bisa didapat dari dukungan keluarga dan lingkungan sekitar. Selain itu, penting untuk mendiskusikan keinginan untuk memberikan ASI eksklusif pada calon suami sejak sebelum menikah, sehingga selama proses suami akan ikut mendukung.

Tabel 3 menunjukkan distribusi ASI eksklusif, berdasarkan variabel-variabel penelitian.

Tabel 3. Proporsi ASI eksklusif dan tidak eksklusif berdasarkan ciri ibu dan dukungan keluarga

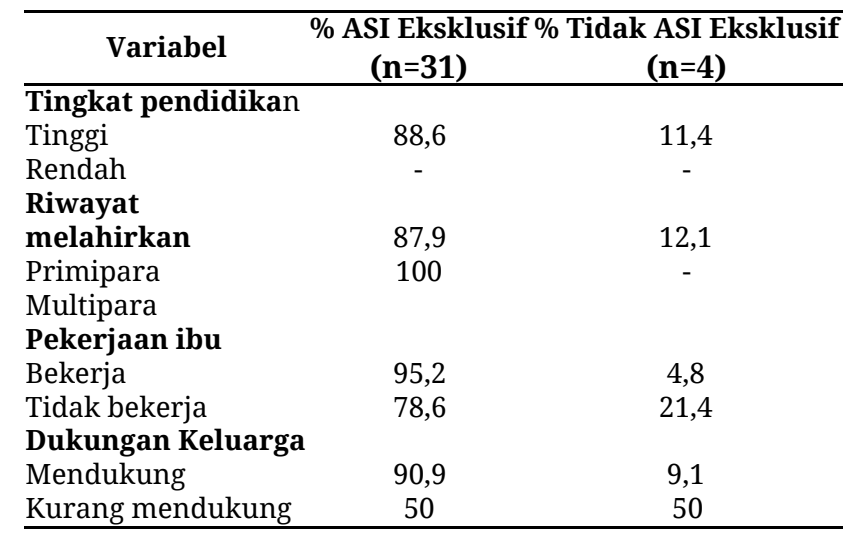

"keluarga jadi kurang support kan jadi tidak percaya diri, tidak percaya diri ya karena itu tadi akhirnya baru setelah 6 bulan itu saya bisa menyusui tanpa susu formula” (informan 2).

"waktu itu anaknya menangis, lalu langsung sama ibu mertua berkata bahwa susunya kurang. Saya sebenarnya protes, saya bisa menyusui, mengapa diberi susu formula” (informan 2).

"ya dari awal milih calon kan sudah ini ya pokoknya saya mau memberi ASI eksklusif, jadi Alhamdulillah lancar. Malah ada dukungan dari kakak ipar yang sebelumnya sudah praktisi. Waktu awal belajar ASI perah juga suami saya, apa-apa semua dia pokoknya” (informan 4).

Responden yang sejak sebelum kehamilan sudah memutuskan untuk menyusui bayi ada 54,3\% dan sebanyak 57,1\% mendapatkan informasi mengenai ASI pada saat melakukan pemeriksaan persalinan. Responden lain mengatakan bahwa petugas kesehatan yang membantu dalam proses persalinan tidak semua memberikan informasi mengenai cara menyusui ataupun IMD jika tidak ditanya terlebih dahulu.

"langsung ditempelin sama dokternya, terus cuma sebentar lagi. 10 menit mungkin. Itu kalau di Sadewa kalau tidak, saya kan sc, kalau tidak request IMD tidak diberi. Tapi kalau yang lahir normal dia memang langsung IMD, tapi kalau yang sc tidak di Sadewa itu." (informan 1)

“...begitu lahir saya pikir di Happy Land itu namanya IMD cuma narok aja, ternyata IMD itu dibiarkan istilahnya. Nah itu tadi begitu ditaruh disini tu dia langsung diam dan langsung tidur. Jadi.. jadi..belum sempat menyusu, tapi tidur gitu dia" (informan 2).

“...kan bingung ini anak mengapa nangis terus? Di tempat bidan itu tidak semuanya ternyata pro ASI eksklusif perawatnya. Jadi begitu tahu menangis itu bukannya disuruh menyusui tapi ini kurang susu ibunya. Lalu kebetulan suami saya juga suami baru, langsung panik itu waktu itu ya sudah langsung diberi susu saja” (informan 2).

"jam 10 bayi diantar, hanya diantar begitu saja tanpa obrolan apapun. Posisi bayi saat diantar tidur. Saya dan suami yang sama-sama minim pengetahuan juga bingung ini bayi diapain ya, cara menyusuinya bagaimana? 1 jam kemudian bayi menangis. Saya minta suami untuk memanggil perawat supaya saya bisa diajarkan menyusui. Perawat datang, baru saya diberi tahu cara menyusui." (informan 3 ).

Semua responden mencari informasi mengenai ASI, terutama dari internet dan media sosial. Sebanyak $37,1 \%$ ibu mengikuti konseling ASI, baik yang dilakukan oleh konselor menyusui AIMI dan dari rumah sakit.

\section{BAHASAN}

Kelas edukasi menyusui yang diadakan oleh AIMI ini mulai rutin diadakan sejak tahun 2013. Namun sayangnya, tidak semua data peserta kelas edukasi terdokumentasikan. Kelas edukasi ini tidak melakukan follow up peserta. Jika mengalami kesulitan selama proses menyusui, ibu dapat menghubungi AIMI dan mendaftar untuk konseling. Konseling menyusui bisa dilakukan di rumah, maupun di tempat ibu bersalin.

Materi dalam kelas edukasi disampaikan oleh konselor menyusui yang juga merupakan anggota AIMI. Untuk dapat menjadi seorang konselor menyusui harus mengikuti pelatihan konseling menyusui terlebih 
dulu. Pelatihan konseling menyusui dengan menggunakan modul 40 jam pedoman WHO/UNICEF dapat meningkatkan pengetahuan dan kemampuan memberikan konseling (8).

Ibu yang mengikuti kelas edukasi prenatal memiliki durasi menyusui yang lebih lama dibandingkan dengan ibu yang tidak mengikuti edukasi prenatal. Namun, tidak terdapat perbedaan durasi menyusui antara kelompok yang datang satu kelas saja dengan kelompok yang mengikuti dua kelas edukasi (9). Dalam penelitian yang lain, disebutkan bahwa tidak terdapat perbedaan pemberian ASI eksklusif pada kelompok yang mendapatkan edukasi mengenai keterampilan praktis dengan kelompok yang mendapatkan edukasi mengenai sikap terhadap pemberian ASI (10).

Responden yang pernah mendapatkan pendidikan kesehatan mengatakan bahwa pendidikan merupakan sumber yang berpengaruh terhadap keputusan ibu memberikan ASI eksklusif. Pendidikan dan pengetahuan memberikan pengaruh positif terhadap keberhasilan ibu memberikan ASI eksklusif (4). Faktor lain yang berpengaruh positif terhadap keberhasilan ASI eksklusif adalah motivasi dan dukungan (11). Pasangan yang bersikap positif terhadap pemberian ASI dapat menentukan keberhasilan ibu menyusui. Mengikuti kelas edukasi menyusui dan kelas edukasi prenatal dapat meningkatkan kemungkinan ibu untuk berhasil menyusui (12).

\section{SIMPULAN}

Tidak terdapat perbedaan antara ibu yang mengikuti satu kelas saja dengan ibu yang mengikuti dua kelas edukasi menyusui terhadap keberhasilan ASI eksklusif. Namun, kelas edukasi menyusui dapat menguatkan keputusan ibu untuk memberikan ASI eksklusif kepada bayi. Dukungan orang terdekat sangat penting untuk mendukung keberhasilan ibu dalam memberikan ASI eksklusif.

\footnotetext{
Abstrak

Tujuan: Penelitian ini bertujuan untuk mengkaji perbedaan keikutsertaan ibu dalam kelas edukasi menyusui AIMI (Asosiasi Ibu Menyusui Indonesia) dan keberhasilan memberikan ASI eksklusif. Metode: Penelitian cross sectional dilakukan melibatkan wawancara mendalam terhadap ibu yang sudah pernah mengikuti kelas edukasi menyusui AIMI Yogyakarta. Hasil: Sebanyak 88,6\% responden memberikan ASI eksklusif. Pada yang mengikuti satu
}

kelas saja, sebanyak 88,9\% memberikan ASI eksklusif, sedangkan $88,6 \%$ pada kelompok yang mengikuti dua kelas edukasi memberikan ASI eksklusif. Tidak terdapat perbedaan antara ibu yang mengikuti satu kelas atau dua kelas edukasi terhadap keberhasilan ASI eksklusif. Simpulan: Penelitian ini memberikan kontribusi pengetahuan bahwa tidak terdapat perbedaan antara ibu yang mengikuti satu kelas atau dua kelas edukasi terhadap keberhasilan ASI eksklusif.

Kata kunci: kelas edukasi; ASI eksklusif; asosiasi ibu menyusui Indonesia

\section{PUSTAKA}

1. Kementerian Kesehatan. Peraturan Pemerintah Republik Indonesia Nomor 33 tentang Pemberian ASI Eksklusif. Jakarta; 2012.

2. Butte NF, Lopez-Alarcon MG, Garza C. Nutrient adequacy of exclusive breastfeeding for the term infant during the first six months of life. 2002.

3. Dinas Kesehatan Provinsi Yogyakarta. Profil Kesehatan Provinsi Yogyakarta tahun 2012; 2012.

4. Fikawati S, Syafiq A. Penyebab keberhasilan dan kegagalan praktik pemberian ASI eksklusif. Kesmas: Jurnal Kesehatan Masyarakat Nasional. 2009;4(3):120-31.

5. World Health Organization. Global strategy for infant and young child feeding; 2003.

6. Chen PG, Johnson LW, Rosenthal MS. Sources of education about breastfeeding and breast pump use: what effect do they have on breastfeeding duration? An analysis of the Infant Feeding Practices Survey II. Maternal and child health journal. 2012;16(7):1421-30.

7. Froozani M, Permehzadeh K, Dorosty Motlagh A, Golestan B. Effect of breastfeeding education on the feeding pattern and health of infants in their first 4 months in the Islamic Republic of Iran. Bulletin World Health Organization. 1999;77:381-5.

8. Rea M, Venancio S, Martines J, Savage F. Counselling on breastfeeding: assessing knowledge and skills. Bulletin World Health Organization. 1999;77:492-8.

9. Reifsnider E, Eckhart D. Prenatal breastfeeding education: its effect on breastfeeding among WIC participants. Journal of Human Lactation. 1997;13(2):121-5.

10. Lumbiganon P, Martis R, Laopaiboon M, Festin MR, Ho JJ, Hakimi M. Antenatal breastfeeding education for increasing breastfeeding duration. The Cochrane Library. 2012.

11. Pinto E, Chaves C, Duarte J, Nelas P, Coutinho E. Maternal affection and motivation for breastfeeding. Procedia-Social and Behavioral Sciences. 2016;217:1028-35.

12. Giugliani ER, Caiaffa WT, Vogelhut J, Witter FR, Perman JA. Effect of breastfeeding support from different sources on mothers' decisions to breastfeed. Journal of human lactation. 1994;10(3):157-61. 
Berita Kedokteran Masyarakat, Volume 33 No. 6 Tahun 2017 